\title{
Incorporation of gluten and hydrolysed gluten proteins have different effects on dough rheology and cookie characteristics.
}

\section{Running tittle}

Effect of gluten proteins on cookies.

Ángela Bravo-Nuñez*, Marta Sahagún, Paula Martínez, Manuel Gómez.

Food Technology Area. College of Agricultural Engineering. University of Valladolid, 34071

Palencia, Spain.

Tel: +34 979108495; fax +34 979-108302

*Corresponding author e-mail: angela.bravo.nunez@gmail.com

\begin{abstract}
This study aims to establish how the substitution of wheat flour by high levels of gluten or hydrolyzed gluten proteins affect sugar-snap cookies properties. An increase in water binding capacity was observed when proteins were present. An increase in the dough elastic modulus was observed for gluten protein but it decreased when hydrolyzed gluten protein was used. Regarding the physical characteristics of the cookies, for the same protein percentage, the presence of gluten protein decreased spread ratio and increased hardness, while hydrolyzed gluten protein increased spread ratio and yielded darker cookies without modifying the hardness. As for sensory characteristics, taste was negatively influenced by hydrolyzed protein and visual acceptability was enhanced when gluten protein was present. Overall acceptability was decreased for the highest levels of hydrolyzed gluten protein. Nevertheless, the highest levels of gluten protein did not modify the acceptability.
\end{abstract}

Keywords: gluten; protein hydrolysates; wheat; rheology; baking. 


\section{Introduction}

In recent years, a rising interest in protein-enriched starchy food products has increased in both the food industry and consumers. The underpinning reason for this interest is related to the growing demand for functional food products. Several studies have reported that higher protein intakes above current recommendations may provide health benefits for the elderly (Nowson \& O'Connell, 2015) and athletes (Lemon et al., 1992). Furthermore, diets with higher protein content may increase thermogenesis and satiety compared to diets with lower protein content (Halton \& Hu, 2004). Therefore, the substitution of carbohydrates by proteins may be beneficial for weight-loss diets. Among proteins, vegetal proteins have been associated with a lower risk of coronary heart disease (Terpstra et al., 1983). Bakery products are a possible vehicle to meet the increasing demand for protein enriched products, among which cookies stand out because of their high acceptance and long shelf life. Due to the high levels of fat and sugar, the influence of proteins in the network of sugar-snap cookies is limited. Even so, protein is not inert in cookie dough, especially during baking (Gaines, 1990). In fact, an inverse correlation between protein content and spread ratio of wheat cookies has been reported by Claughton \& Pearce (1989), Bajaj et al., (1991), and Pareyt et al., (2008), who studied the influence of the addition of different proteins at levels below 30\%. It would be interesting to know how higher gluten protein levels influence cookie properties, but to the best of our knowledge this has not been studied. Another aspect of interest that has been minimally studied is the effect of hydrolysis on the behaviour and properties of proteins in cookies. Ribotta et al., (2012) and Goel et al., (1999) found that incorporation of enzymatically hydrolyzed proteins decreased the viscosity and rheological profiles of starchy pastes. In fact, Chaudhary et al., (2017) reported that the wheat varieties with proteins with lower molecular weight were better for cookie making. Furthermore, the use of proteases can also improve the quality of cookies (Kara et al., 2005). Nevertheless, to the best of our knowledge the incorporation of hydrolysed gluten to enriched cookies has never been studied.

The aim of this study was to evaluate the effect of the substitution of wheat flour by high levels (15, 30 and $45 \mathrm{~g} \mathrm{Kg}^{-1}$ flour basis) of both gluten or hydrolysed gluten proteins on dough rheology and sugar-snap cookie quality. 


\section{Materials and methods}

\subsection{Materials}

Wheat flour (117.7 $\mathrm{g} \mathrm{Kg}^{-1}$ moisture content, (HARICAMAN all purpose) was supplied by Harinas de Castilla la Mancha S.L. (Toledo, Spain). Vital wheat gluten (GP) with $87 \mathrm{~g} \mathrm{Kg}^{-1}$ protein content (dry basis), and Nutralys W wheat gluten (HGP), obtained by enzymatic hydrolysis of wheat gluten and with $82 \mathrm{~g} \mathrm{Kg}^{-1}$ protein content (dry basis), were provided by Roquette (Leutrem, France). The following ingredients were also used: 100\% vegetable margarine (Argenta crema, Puratos, Barcelona, Spain), white sugar (AB Azucarera Iberica, Valladolid, Spain) and sodium bicarbonate (Manuel Riesgo S.A., Madrid, Spain).

\subsection{Methods}

\subsubsection{Preparation of the flour-protein mixtures}

Flour-protein mixtures were made by the substitution of wheat flour by GP or HGP in the following levels: 150,350 and $450 \mathrm{~g} \mathrm{Kg}^{-1}$. Mixtures were dry blended.

\subsubsection{Flour and flour-protein mixtures hydration properties}

Water binding capacity (WBC) was analysed following AACC method 56-36 (AACC, 2012). WBC was analysed in duplicate.

\subsubsection{Cookie making procedure}

First, the moisture of the flour/flour-protein mixtures was adjusted to $150 \mathrm{~g} \mathrm{Kg}^{-1}$. Afterwards the ingredients (as $\mathrm{g} \mathrm{Kg}^{-1}$ dough basis) were mixed as follows: the margarine (192) was heated in the microwave (1000 watts for $1 \mathrm{~min}$ ) and creamed together with the sugar (308) in a Kitchen Aid 5KPM50 mixer (Kitchen Aid, Benton Harbor, Michigan, USA) using a flat beater at speed 4 for $180 \mathrm{~s}$, with intermediate scraping every $60 \mathrm{~s}$. Then, the water (62) was added and mixed at speed 4 for $120 \mathrm{~s}$, with a scraping steep at the end. Finally, the flour/ flour-protein mixture (428) and the sodium bicarbonate (9) were added and mixed at speed 2 for 120 s, with scraping every $30 \mathrm{~s}$. Table 1 shows the formulation for each cookie type. The dough was wrapped with plastic, allowed to rest for $30 \mathrm{~min}$ at $25^{\circ} \mathrm{C}$ and then subsequently laminated with a Salva L-500-J sheeter (Salva, Lezo, Spain) using a gap of $6.00 \mathrm{~mm}$. After the resting period the dough was cut with a circular cookie cutter (internal diameter, $40 \mathrm{~mm}$ ) and the resulting cookies were baked in an electric modular oven for $14 \mathrm{~min}$ at $185^{\circ} \mathrm{C}$. Cookies were cooled down for $60 \mathrm{~min}$ at room temperature before packing them in plastic bags and storing them at $24{ }^{\circ} \mathrm{C}$. All cookies were made in duplicate. 


\subsubsection{Dough rheology}

The rheological behaviour of doughs was analysed using a controlled strain rheometer (Thermo Fisher Scientific, Schwerte, Germany) equipped with a parallel-plate geometry (60 mm diameter titanium serrated plate-PP60 Ti) and a water bath (Thermo Fisher Scientific, Schwerte, Germany) at $25^{\circ} \mathrm{C}$ following the methodology of Mancebo et al., (2016). Circular dough pieces (3 mm height and $60 \mathrm{~mm}$ width) were placed in the rheometer and compressed with a gap of 3 $\mathrm{mm}$. Samples were rested for $300 \mathrm{~s}$ before measuring. A strain sweep test in the range of 0.1 to $100 \mathrm{~Pa}$ at a constant frequency $(1 \mathrm{~Hz})$ was conducted to identify the strain value included in the linear viscoelastic region. This strain value was used to perform a frequency sweep test in a frequency range from 10 to $0.1 \mathrm{~Hz}$. Elastic modulus $\left(\mathrm{G}^{\prime}[\mathrm{Pa}]\right)$, viscous modulus $\left(\mathrm{G}^{\prime \prime}[\mathrm{Pa}]\right)$, and loss factor $(\tan \delta)$ were obtained. Samples were analysed in duplicate.

\subsubsection{Cookie characteristics}

Cookie characteristics were measured following the methodology described by Mancebo et al., (2016).

Cookie texture was measured by a "three-point bending" test, using a TA-XT2 texture analyser (Stable Microsystems, Surrey, United Kingdom) and a sounding line HDP/3PB with a test speed of $2.0 \mathrm{~mm} / \mathrm{s}$. The maximum force $(\mathrm{N})$ to break the cookies was measured.

Diameter and thickness of the cookies were measured with a calliper. The diameter of each cookie was measured twice, perpendicularly, in order to calculate the average diameter. Then, the spread factor of the cookies was calculated by dividing the average width by the thickness of the cookies.

Colour was measured using a Minolta CM-508i spectrophotometer (Minolta Co., Ltd, Japan) with the D65 standard illuminant and the $2^{\circ}$ standard observer. Measurements were made at the centre of the upper surface (crust). The results were expressed in the CIE L*a*b* colour space.

Six cookies of each batch were measured one day after baking.

\subsubsection{Consumer test}

Sensorial hedonic evaluation was performed by 80 volunteers, who were regular consumers of cookies between the ages of 18 and 64 years, using cookies prepared the previous day following the methodology described by Mancebo et al., (2016). In order to avoid panellist fatigue, only five cookies were tasted. The control sample and the enriched cookies with 30 and $45 \%$ of GP and HGP were chosen for the sensory evaluation. The cookies were randomly placed in white 
plastic plates and coded with four-digit numbers. Panellists evaluated appearance, odour, texture, taste and overall acceptability using a hedonic scale of 9 points, were 1 corresponded to "I dislike so much" and 9 to "I like so much".

\subsubsection{Statistical analysis}

Data were studied using one-way analysis of variance (simple ANOVA). When significant $(p<0.05)$ differences were found, Fisher's least significant differences (LSD) test was used to determine the differences among means. Statistical analyses were completed using Statgraphics Centurion XVI software (StatPoint Technologies Inc, Warrenton, EE.UU).

\section{Results and Discussion}

\subsection{Flour and flour-protein mixtures hydration properties}

Water binding capacity (WBC) results are plotted in Figure 1. An increasing trend was observed when the content of both proteins, GP and HGP, increased. However, significant differences were only discerned for the highest percentage of both proteins (45\%), but there were no significant differences between both protein types. Al igual que en nuestro caso, tanto Mancebo et al., (2016) como Traynham et al (2007) observaron un incremento del WBC cuando se increment el porcentaje de proteínas en mezclas con harina de cereales also observed a boosting effect of protein (pea protein) regarding WBC in flour-starch-protein mixtures. This also is in agreement with the results obtained by Traynham et al., (2007), who studied the water absorption capacity for wheat-soy flour blends. Moreover, Pareyt \& Delcour (2008) reported that wheat protein absorbs twice its weight in water and therefore the protein content has an important effect on hydration properties. Thus, the increment of the WBC may be attributed to the higher water binding ability of gluten proteins than wheat flour. The lack of differences between mixtures with different protein type is odd, as more soluble proteins should give lower WBC values, and indeed other studies reached this conclusion (Shin et al., 2010). The lack of differences between proteins may be related with the fact that flour is the mayor component in the mixtures and that some bonding between flour molecules and proteins may occur.

\subsection{Dough rheology}

The rheological behavior of the doughs is plotted in Figure 2. Both G' and G', were influenced by the presence of proteins. As protein content increased, GP increased G' while HGP decreased G', although no significant differences were observed between 30 and $45 \%$ of substitution in 
both cases. Nevertheless, changes in rheological behaviour of the doughs when substituting flour by protein were not drastic. This is because short doughs, as snap-cookie doughs are, have high levels of fat and sugar, and low levels of water. Therefore, the development of gluten network is minimal (Pareyt \& Delcour, 2008).

The curve slope of doughs containing HGP seems to be more pronounced than that of the control dough, evidencing a higher dependency on the frequency. Regarding G”, in general all samples increased this value with higher protein content. The increase of viscous moduli was more evident for doughs with GP.

Results of $\tan \delta$ indicate that the addition of both GP and HGP resulted in lower consistency, as $\tan \delta$ values increased. This increase of $\tan \delta$ was more pronounced with HGP and with higher protein levels. As reported by Ribotta et al., (2012), the addition of proteins led to networks that shifted from an elastic-like nature to a more viscous-like one. Grinberg \& Tolstoguzoy (1997) reported that when two different biopolymers interact, they can either segregate or associate, although in general polysaccharides and proteins are thermodynamically incompatible. Taking this into account, the effect of proteins on rheological behaviour may be related both with interactions among starch granules and hydrophobic groups of GP and HGP, and with the selfaggregation of proteins. In this way, the differences between the effect of GP and HGP may be related with the size (i.e. larger effect when using GP) and with the hydrophobic groups (probably more numerous when using HGP) as reported by Agyare et al., (2009). GP likely adsorbs to starch to a greater extent than HGP (Eliasson \& Therneld, 1990), and this could justify the viscosity increase with respect to the control. On the contrary, HGP, which seems to have lower molecular weight than GP and possesses more numerous hydrophobic groups, does not absorb that well to starch and therefore leads to decreased viscosity with respect to the control.

\subsection{Cookie characteristics}

\subsubsection{Dimensions}

Table 2 and Figure 3 show cookies dimensions, colour and hardness. In general, the addition of GP increased cookie height and decreased cookie diameter, reducing the spread ratio significantly. Althoug gluten network in sugar-snap cookies is limited, there are studies that state that flours with low gluten content and weak gluten strength are generally desired for good sugar-snap cookie baking (Gaines, 1990; Hou et al., 1996; Kaldy et al., 1993), which may lead 
to think that higher hardness can be related with gluten network formation. There are at least two theories concerning the mechanism by which cookie dough stops expanding (spreading) during baking well described by Pareyt \& Delcour (2008). The one proposed by Slade el al., (1989) claims that cookie dough actually does not "set," but that proteins in good quality flours (soft wheat flours) exhibit viscous expansion and creep followed by structural collapse, while poor quality cookie flours (hard wheat flours) exhibit elastic expansion followed by elastic shrinkage. This elastic shrinkage is probably related with a tri-dimensional network boosted by gluten proteins.

Gluten influence should not be ignored, but Souza et al,. (1994) concluded that the total protein content is more important for sugar-snap cookie quality than is the composition of that protein. Other authors also observed lower expansion in enriched cookies with the addition of sunflower (Claughton \& Pearce, 1989), canola (Gerzhova et al., 2016), rice bran (Yadav et al., 2011) or gluten-soy (Singh \& Mohamed, 2007) proteins, in agreement with the presented results for GP. However, when adding HGP, all cookies had a significantly smaller thickness with respect to both the control and cookies with GP, but width differences with the control were not significant; therefore, the addition of HGP increased the spread ratio. The differences in spread ratio between cookies with GP and HGP may be related with both of the lower rheology values (G' and G') of HGP doughs because of protein differences explained previously, which may favour expansion during baking time. This aligns with the findings of Miller \& Hoseney (1997), who showed with time-lapse photography that, during baking, the diameter of sugar-snap cookies increases linearly with time and then suddenly sets. Therefore, it is logical to think that more elastic doughs flow less than viscous doughs. The importance of and early flow for cookie diameter was already pointed out by Pareyt et al., (2008).

\subsubsection{Texture}

Cookies with GP presented higher hardness than the control, being this difference was more pronounced with increasing substitution percentage. Other authors also observed an increment of hardness with the addition of rice bran protein (Yadav et al., 2011) or dairy proteins (Sarabhai \& Prabhasankar, 2015; Gani et al., 2015). This effect aligns with the results of Pareyt et al., (2008) in their study of gluten-starch blends. Pareyt \& Delcour (2008) explained this effect by the fact that proteins tend to associate during baking due to the expansion of gas cells, which forces the proteins to be closer to each other. In addition, Gaines (1990) confirmed that some 
functional associations of soft wheat proteins occurs during mixing of sugar-snap cookie dough. This study also affirmed that sugar-snap cookie hardness is sensitive to increased association of soft wheat proteins.

In contrast to GP, cookies containing HGP did not present significant differences compared to the control. This can be justified by the fact that the hydrolysis of gluten modified protein structure, giving rise to different chain lengths and molecular sizes of the peptides (Chen et al., 2012). Thus, hydrolysis leads to shorter protein chains modifying the interactions between proteins. The higher spread ratio of cookies with HGP could also contribute to the reduction in hardness, as the difference in dimensions with respect to the control could compensate for the hardening effect of protein interactions. In fact, a negative correlation between spread ratio and hardness was obtained in this study $(\mathrm{r}=-0.8681, \mathrm{p}<0.01)$. This inverse correlation was also observed by Sert et al., (2016), Singh \& Mohamed (2007) and Yadav et al., (2011) in different protein enriched cookies.

\subsubsection{Color}

The incorporation of GP decreased the $\mathrm{L}^{*}$ values of the cookies with the highest protein content, although no significant differences were observed. On the contrary, the addition of HGP led to lower $\mathrm{L}^{*}$ values, which produced darker cookies. The higher the amount of HGP, the lower the luminance values. Some authors reported that the darkness of cookies is enhanced as protein content increases due to a high degree of non-enzymatic browning (Conforti \& Lupano, 2004; Wani et al., 2010; Sarabhai \& Prabhasankar, 2015; Mancebo et al., 2016). Changes in cookies colour are produced due to Maillard reactions between reducing sugars and amino side-chains of proteins (Wani et al., 2010; Pérez et al., 2013). Protein hydrolysis produces particles with smaller size, thereby increasing the number of reactive sites, which leads to greater surface available to interact with reducing sugars (Gani et al., 2015). This may explain the lower L* values of the cookies with HGP. The smaller cookie thickness could also have affected the decrease of luminance, as by increasing the temperature of the dough faster, these cookies lost their moisture faster, and therefore Maillard reactions would start sooner.

In general, the addition of protein increased $a^{*}$ values, with the increase being more evident with higher protein content. On the other hand, no significant differences were found with respect to the control for $b^{*}$, except for samples with 30 and 45\% HGP for which $b^{*}$ decreased. Sarabhai et al., (2015), who added up to $10 \%$ whey protein, also observed that $\mathrm{a}^{*}$ values 
increased and $b^{*}$ values decreased when increasing the amount of protein. The differences between cookies with GP and HGP may be due to the way in which proteins affect Maillard reactions, which are responsible of the cookie color, as discussed previously.

\subsection{Consumer test}

The results obtained from sensorial evaluation are shown in Table 3. Regarding odour and texture, the addition of protein did not result in significant differences compared to the control. The incorporation of GP significantly increased the scores of cookie appearance, being higher in relation to the percentage of protein. However, for HGP no significant differences with respect to the control were found. Regarding taste, no significant differences were observed for cookies with GP, while cookies with HGP presented significantly lower values. This may be due to the presence of bitter compounds produced during Maillard reactions that many people do not find favourable (Jiang \& Peterson, 2013). These reactions were more abundant for cookies with HGP, since as it can be observed in Table 3, the hydrolyzed gluten provides darker colour in cookies. Moreover, the enzymatic hydrolysis can produce bitter compounds due to the release of small peptides from excessive enzymatic action (Day et al., 2006). For overall acceptability, cookies with GP and HGP did not show significant differences compared to the control sample, except for those with $45 \%$ of HGP, which presented a significantly lower value. This could be probably explained by the dark colour and poor taste.

\section{Conclusion}

Although no significant differences were observed for WBC between mixtures with GP and HGP, these proteins affected the rheology of the doughs differently. As a consequence of these differences, cookies with GP were higher and smaller in size as well as harder than the control, while the opposite effect occurred with HGP. In addition, differences in cookie colour were also observed, as cookies with GP were lighter than the cookies with HGP. Finally, it was also observed that the type of protein can also influence cookie acceptability, mainly with higher protein percentages. In this way, cookies with $45 \%$ of HGP had worse scores than the control or GP enriched cookies with the same percentage of protein. These differences are more evident in cookie flavour and may be related to the different behaviour of both proteins in Maillard reactions, as reflected by the differences of colour between cookies. 
In general terms, it can be stated that both percentage of incorporation and hydrolysis of gluten proteins are important parameters to consider in the protein enrichment of cookies, as they affect the behaviour of the doughs, characteristics and acceptance of the protein enriched cookies. This research will help provide relevant insights for improving the quality of protein enriched cookies.

\section{Acknowledgements}

The authors acknowledge the financial support of the Spanish Ministry of Economy and Competitiveness (Project AGL2014-52928-C2) and the European Regional Development Fund (FEDER). The authors are also grateful to Roquette Laisa for supplying the raw materials.

\section{References}

AACC International (2012). Approved methods of the American Association of Cereal Chemists International. Method 56-36 (WBC) (11th ed.). St Paul, MN: American Association of Cereal Chemists.

Agyare, K. K., Addo, K., \& Xiong, Y. L. (2009). Emulsifying and foaming properties of transglutaminase-treated wheat gluten hydrolysate as influenced by $\mathrm{pH}$, temperature and salt. Food Hydrocolloids, 23, 72-81.

Bajaj, M., Kaur, A., \& Sidhu, J. S. (1991). Studies on the development of nutritious cookies utilizing sunflower kernels and wheat germ. Plant Food for Human Nutrition, 41, 381-387.

Chaudhary, N., Dangi, P., \& Khatkar, B. S. (2017). Fractionation of unreduced gluten proteins on SEC and their relationship with cookie quality characteristics. Journal of Food Science and Technology, 2, 342-348.

Chen, J. S., Wang, S. Y., Deng, Z. Y., Zhang, X. Y., Feng, S. L., Yuan, H. Q., \& Tian, J. C. (2012). Effects of enzymatic hydrolysis of protein on the pasting properties of different types of wheat flour. Journal of Food Science, 77, 546-550.

Claughton, S. M., \& Pearce, R. J. (1989). Protein enrichment of sugar snap cookies with sunflower protein isolate. Journal of Food Science, 54, 354-356.

Conforti, P. A., \& Lupano, C. E. (2004). Functional properties of biscuits with whey protein concentrate and honey. International Journal of Food Science and Technology, 39, 745-753. 
Day, L., Augustin, M. A., Batey, I. L., \& Wrigley, C. W. (2006). Wheat-gluten uses and industry needs. Trends in Food Science \& Technology, 17, 82-90.

Eliasson, A. C., \& Tjerneld, E. (1990). Adsorption of wheat proteins on wheat starch granules. Cereal Chemistry, 67, 366-372.

Gaines, C. S. (1990). Influence of chemical and physical modification of soft wheat protein on sugar-snap cookie dough consistency, cookie size, and hardness. Cereal Chemistry, 67, 73-77.

Gani, A., Broadway, A. A., Ahmad, M., Ashwar, B. A., Wani, A. A., Wani, S. M., Masoodi., F. A., \& Khatkar, B. S. (2015). Effect of whey and casein protein hydrolysates on rheological, textural and sensory properties of cookies. Journal of Food Science and Technology, 52, 57185726.

Gerzhova, A., Mondor, M., Benali, M., \& Aider, M. (2016). Incorporation of canola proteins extracted by electroactivated solutions in gluten-free biscuit formulation of rice-buckwheat flour blend: assessment of quality characteristics and textural properties of the product. International Journal of Food Science \& Technology, 51, 814-827.

Grinberg, V. Y., \& Tolstoguzov, V. B. (1997). Thermodynamic incompatibility of proteins and polysaccharides in solutions. Food Hydrocolloids, 11, 145-158.

Goel, P. K., Singhal, R. S., \& Kulkarni, P. R. (1999). Studies on interactions of corn starch with casein and casein hydrolysates. Food Chemistry, 64, 383-389.

Halton, T. L., \& Hu, F. B. (2004). The effects of high protein diets on thermogenesis, satiety and weight loss: A critical review. Journal of the American College of Nutrition, 23, 373-385.

Hou, G., Yamamoto, H., \& Ng, P. K. W. (1996). Relationships of quantity of gliadin subgroups of selected U.S. soft wheat fours to rheological and baking properties. Cereal Chemistry. 73, $352-357$.

Jiang, D., \& Peterson, D. G. (2013). Identification of bitter compounds in whole wheat bread. Food Chemistry, 141, 1345-1353.

Kaldy, M. S., Kereliuk, G. R., \& Kozub, G. C. (1993). Influence of gluten components and flour lipids on soft white wheat quality. Cereal Chemistry. 70, 77-80

Kara, M., Sivri, D., \& Köksel, H. (2005). Effects of high protease-activity flours and commercial proteases on cookie quality. Food Research International, 38, 479-486. 
Lemon, P. W., Tarnopolsky, M. A., MacDougall, J. D., \& Atkinson, S. A. (1992). Protein requirements and muscle mass/strength changes during intensive training in novice bodybuilders. Journal of Applied Physiology, 73, 767-775.

Mancebo, C. M., Rodriguez, P., \& Gómez, M. (2016). Assessing rice flour-starch-protein mixtures to produce gluten free sugar-snap cookies. LWT-Food Science and Technology, 67, 127-132.

Miller, R. A., \& Hoseney, R. C. (1997). Factors in hard wheat flour responsible for reduced cookie spread. Cereal Chemistry, 74, 330-336.

Nowson, C., \& O'Connell S. (2015). Protein requirements and recommendations for older people: A review. Nutrients, 7, 6874-6899.

Pareyt, B., \& Delcour, J. A. (2008). The role of wheat flour constituents, sugar, and fat in low moisture cereal based products: a review on sugar-snap cookies. Critical Reviews in Food Science and Nutrition, 48, 824-839.

Pareyt, B., Wilderjans, E., Goesaert, H., Brijs, K., \& Delcour, J. A. (2008). The role of gluten in a sugar-snap cookie system: A model approach based on gluten-starch blends. Journal of Cereal Science, 48, 863-869.

Pérez, S., Matta, E., Osella, C., de la Torre, M., \& Sánchez, H. D. (2013). Effect of soy flour and whey protein concentrate on cookie color. LWT-Food Science and Technology, 50, 120-125.

Ribotta, P. D., Colombo, A., \& Rosell, C. M. (2012). Enzymatic modifications of pea protein and its application in protein-cassava and corn starch gels. Food Hydrocolloids, 27, 185-190.

Sarabhai, S., Indrani, D., Vijaykrishnaraj, M., Milind, Kuman, V. A., \& Prabhasankar, P. (2015). Effect of protein concentrates, emulsifiers on textural and sensory characteristics of gluten free cookies and its immunochemical validation. Journal of Food Science Technology, 52, 37633772 .

Sarabhai, S., \& Prabhasankar, P. (2015). Influence of whey protein concentrate and potato starch on rheological properties and baking performance of Indian water chestnut flour based gluten free cookie dough. LWT - Food Science and Technology, 63, 1301-1308.

Sert, D., Demir, M. K., \& Ertaş, N. (2016). Rheological, physical and sensorial evaluation of cookies supplemented with dairy powders. Food Science and Technology International, 22, 196202. 
Shin, M., Gang, D. O., \& Song, J. Y. (2010). Effects of protein and transglutaminase on the preparation of gluten-free rice bread. Food Science and Biotechnology, 19, 951-956.

Singh, M., \& Mohamed, A. (2007). Influence of gluten-soy protein blends on the quality of reduced carbohydrates cookies. LWT-Food Science and Technology, 40, 353-360.

Slade, L., Levine, H., \& Finley, J. W. (1989). Protein-water interactions: Water as a plasticizer of gluten and other protein polymers. In: Protein Quality and the Effects of Processing. pp. 9124. Phillips, D., and Finley, J. W., Eds., Marcel Dekker, New York.

Terpstra, A. H., Hermus, R. J., \& West, C. E. (1983). The role of dietary protein in cholesterol metabolism. World Review of Nutrition and Dietetics, 42, 1-55.

Traynham, T. L., Myers, D. J., Carriquiry, A. L., \& Johnson, L. A. (2007). Evaluation of waterholding capacity for wheat-soy flour blends. Journal of the American Oil Chemists' Society, 84, 151-155.

Wani, A. A., Sogi, D. S., Singh, P., Sharma, P., \& Pangal, A. (2010). Dough-handling and cookie-making properties of wheat flour-watermelon protein isolate blends. Food Bioprocess Technology, 5, 1612-1621.

Yadav, R. B., Yadav, B. S., \& Chaudhary, D. (2011). Extraction, characterization and utilization of rice bran protein concentrate for biscuit making. British Food Journal, 113, 1173-1182. 
Table 1. Ingredients of the cookies

\begin{tabular}{cccccccc} 
Sample & Margarine & Sugar & Water & $\begin{array}{c}\text { Sodium } \\
\text { bicarbonate }\end{array}$ & Flour & $\begin{array}{c}\text { Gluten } \\
\text { protein }\end{array}$ & $\begin{array}{c}\text { Hydrolysed } \\
\text { gluten protein }\end{array}$ \\
\hline CONTROL & 192 & 308 & 62 & 9 & 428 & - & - \\
GP15 & 192 & 308 & 62 & 9 & 363.8 & 64.2 & - \\
GP30 & 192 & 308 & 62 & 9 & 299.6 & 128.4 & - \\
GP45 & 192 & 308 & 62 & 9 & 235.4 & 192.6 & - \\
HGP15 & 192 & 308 & 62 & 9 & 363.8 & - & 64.2 \\
HGP30 & 192 & 308 & 62 & 9 & 299.6 & - & 128.4 \\
HGP45 & 192 & 308 & 62 & 9 & 235.4 & - & 192.6 \\
\hline
\end{tabular}

All values are in $g \mathrm{Kg}^{-1}$ (dough basis).

Table 2. Values obtained for hydration properties.

\begin{tabular}{cccccccc} 
Sample & Thickness $(\mathrm{mm})$ & Width $(\mathrm{mm})$ & Spread ratio & $L^{*}$ & $a^{*}$ & $b^{*}$ & Hardness $(N)$ \\
\hline CONTROL & $6.04 \mathrm{bc}$ & $59.72 \mathrm{~cd}$ & $9.90 \mathrm{c}$ & $67.97 \mathrm{~cd}$ & $5.35 \mathrm{~b}$ & $22.89 \mathrm{~b}$ & $22.58 \mathrm{a}$ \\
GP15 & $6.92 \mathrm{~d}$ & $56.57 \mathrm{bc}$ & $8.20 \mathrm{~b}$ & $69.43 \mathrm{~d}$ & $4.05 \mathrm{a}$ & $23.24 \mathrm{~b}$ & $39.31 \mathrm{~b}$ \\
GP30 & $6.85 \mathrm{~cd}$ & $53.63 \mathrm{ab}$ & $7.85 \mathrm{ab}$ & $64.69 \mathrm{~cd}$ & $6.39 \mathrm{c}$ & $22.22 \mathrm{~b}$ & $44.14 \mathrm{~b}$ \\
GP45 & $7.86 \mathrm{e}$ & $50.95 \mathrm{a}$ & $6.51 \mathrm{a}$ & $61.96 \mathrm{bc}$ & $7.04 \mathrm{c}$ & $21.11 \mathrm{~b}$ & $55.45 \mathrm{c}$ \\
HGP15 & $5.34 \mathrm{ab}$ & $59.43 \mathrm{~cd}$ & $11.18 \mathrm{~cd}$ & $62.88 \mathrm{~cd}$ & $9.22 \mathrm{~d}$ & $21.27 \mathrm{~b}$ & $22.18 \mathrm{a}$ \\
HGP30 & $4.98 \mathrm{a}$ & $61.68 \mathrm{~d}$ & $12.41 \mathrm{de}$ & $55.05 \mathrm{ab}$ & $10.74 \mathrm{e}$ & $15.39 \mathrm{a}$ & $22.38 \mathrm{a}$ \\
HGP45 & $4.88 \mathrm{a}$ & $62.32 \mathrm{~d}$ & $12.83 \mathrm{e}$ & $52.01 \mathrm{a}$ & $11.98 \mathrm{f}$ & $14.17 \mathrm{a}$ & $21.81 \mathrm{a}$ \\
\hline Sta. error & 0.25 & 1.33 & 0.44 & 2.12 & 0.25 & 1.52 & 2.28
\end{tabular}

Spread ratio: width/thickness. Hardness (N): the maximum force. $H / t(N / s):$ the maximum forceltime of displacement at rupture. GP (Gluten protein). HGP (Hydrolysed gluten protein). Numbers on the sample column refer to protein percentage in the flour-protein mixture. The values with the same letter in the same column do not present significant differences $*(p<0,05)$. 
Table 3. Consumer test results of cookies.

\begin{tabular}{cccccc} 
Sample & Appearance & Odour & Texture & Taste & Overall acceptability \\
\hline CONTROL & $5.96 \mathrm{a}$ & $6.0 \mathrm{a}$ & $6.09 \mathrm{a}$ & $6.26 \mathrm{c}$ & $6.29 \mathrm{~b}$ \\
GP30 & $6.46 \mathrm{~b}$ & $6.26 \mathrm{a}$ & $5.75 \mathrm{a}$ & $6.05 \mathrm{bc}$ & $6.34 \mathrm{~b}$ \\
GP45 & $6.95 \mathrm{c}$ & $6.25 \mathrm{a}$ & $5.7 \mathrm{a}$ & $5.98 \mathrm{bc}$ & $6.25 \mathrm{~b}$ \\
HGP30 & $6.39 \mathrm{ab}$ & $6.13 \mathrm{a}$ & $6.05 \mathrm{a}$ & $5.51 \mathrm{ab}$ & $5.94 \mathrm{~b}$ \\
HGP45 & $6.11 \mathrm{ab}$ & $6.0 \mathrm{a}$ & $5.99 \mathrm{a}$ & $5.09 \mathrm{a}$ & $5.44 \mathrm{a}$ \\
\hline Sta. error & 0.16 & 0.17 & 0.19 & 0.20 & 0.17
\end{tabular}

GP (Gluten protein). HGP (Hydrolysed gluten protein). Numbers on the sample column refer to protein percentage in the flour-protein mixture. The values with the same letter in the same column do not present significant differences $*(p<0,05)$.

Figure 1. Water Binding Capacity (WBC) of protein-flour mixtures. GP (Gluten protein). HGP (Hydrolysed gluten protein). The columns with the same letter do not present significant differences $*(\mathrm{p}<0,05)$.

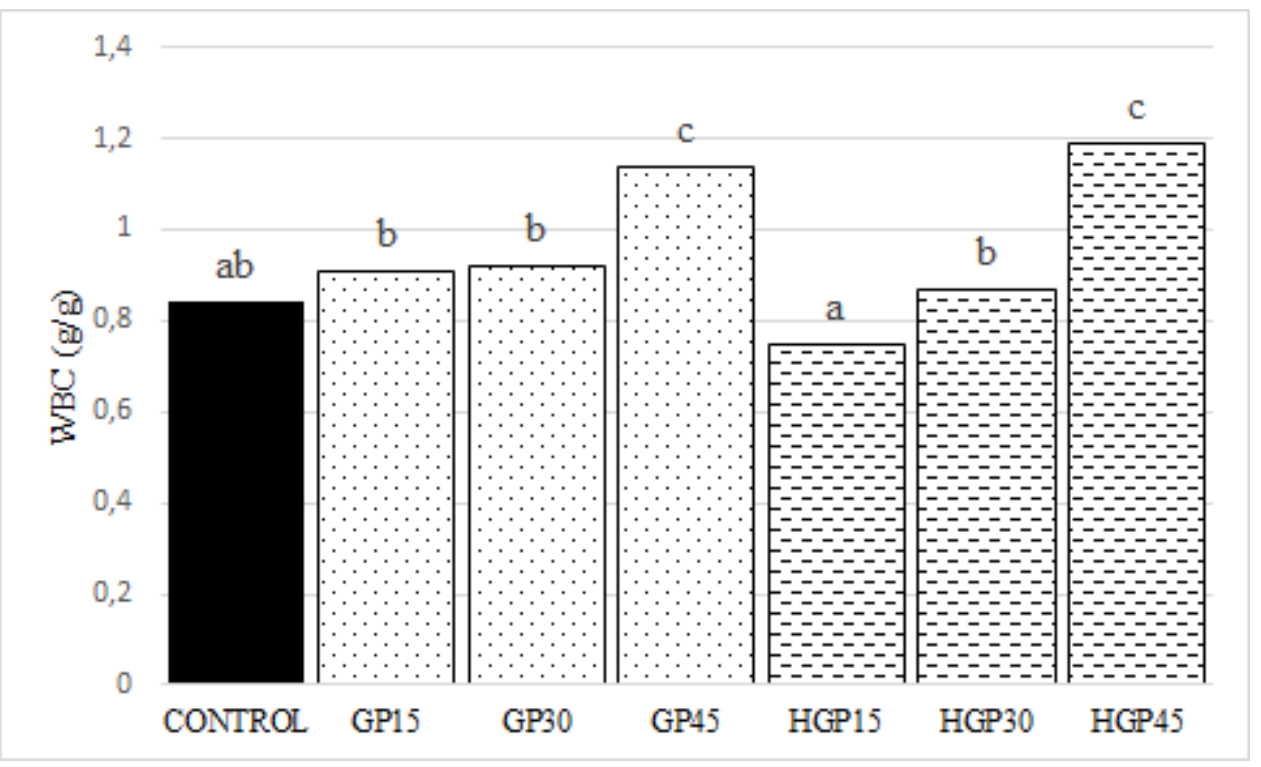


Figure 2. Dynamic oscillatory test results of the doughs with different types of protein. GP (Gluten protein). HGP (Hydrolysed gluten protein). A) Elastic moduli (G'). B) Viscous moduli (G'). C) Loss factor $(\tan \delta)$.

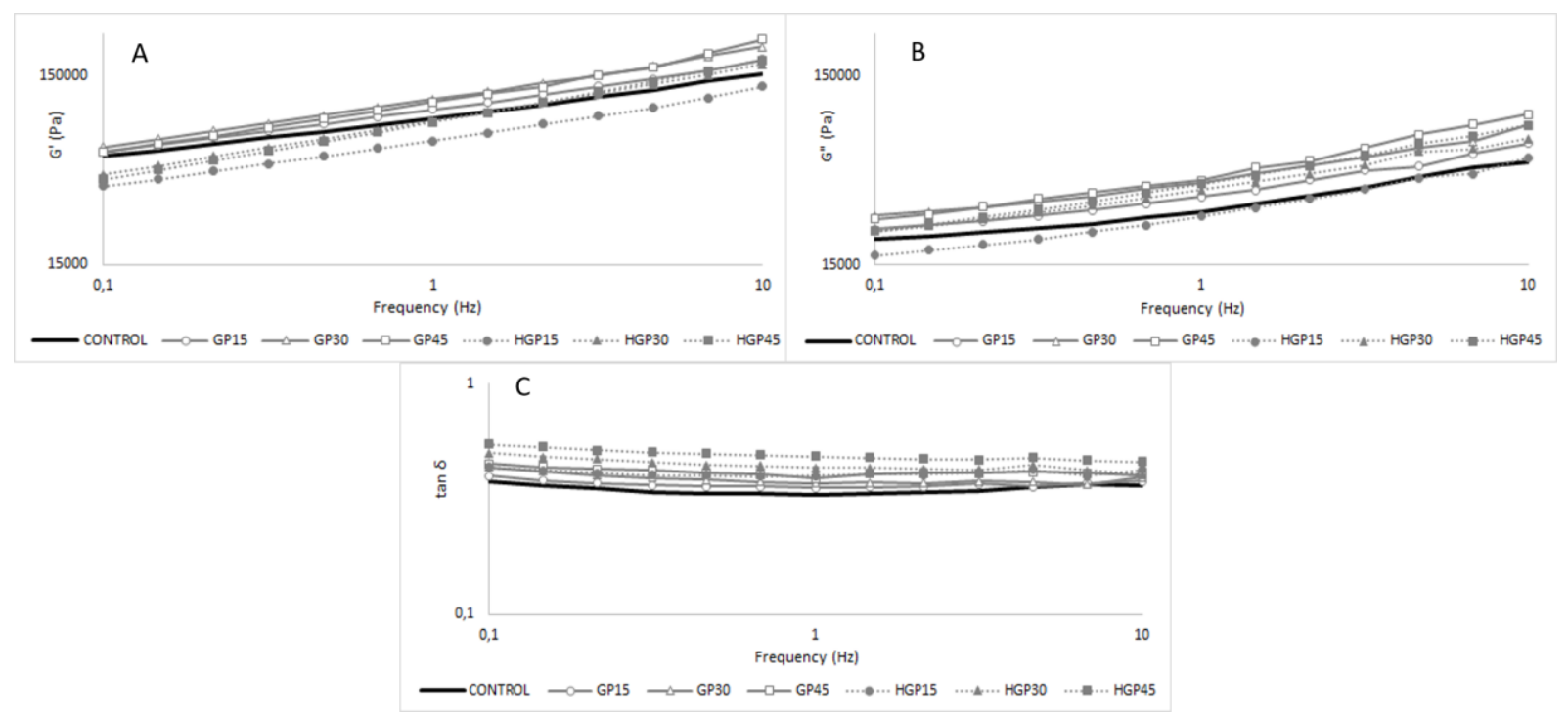


Figure 3. Images of cookies with different types and quantities of protein. GP (Gluten protein). HGP (Hydrolysed gluten protein).

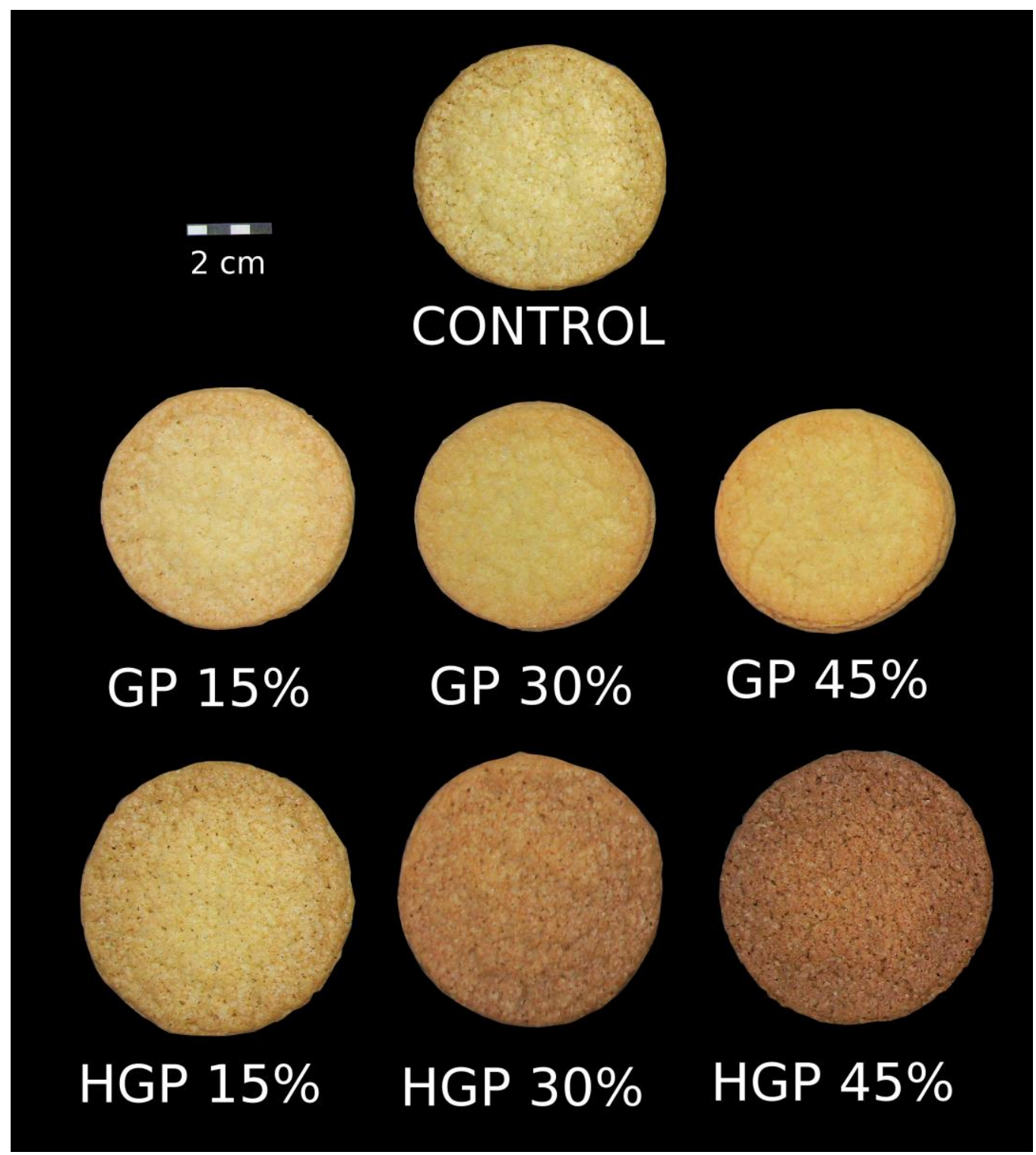

